\title{
Anthropic Impacts on Microbiota and Chemical Properties of Cerrado Soil Through Soybean Cultivation
}

\author{
J. Henrique ${ }^{1,2}$, J. M. R. da Luz ${ }^{3}$, J. J. Carvalho ${ }^{1,2,4}$, J. G. D. Silva ${ }^{1,2}$, J. E. C. Silva ${ }^{1} \&$ E. A. dos Santos ${ }^{4}$ \\ ${ }^{1}$ Universidade Federal do Tocantins, Palmas, TO, Brazil \\ ${ }^{2}$ Centro Universitário Luterano de Palmas, Palmas, TO, Brazil \\ ${ }^{3}$ Universidade Federal de Alagoas, Maceió, AL, Brazil \\ ${ }^{4}$ Instituto Federal do Tocantins, Palmas, TO, Brazil \\ Correspondence: J. E. C. Silva, Universidade Federal do Tocantins, Palmas, TO, Brazil. Tel: 55-063-3232-8007. \\ E-mail: jecs@mail.uft.edu.br
}

\author{
Received: August 30, $2018 \quad$ Accepted: October 23, $2018 \quad$ Online Published: December 15, 2018 \\ doi:10.5539/jas.v11n1p274 URL: https://doi.org/10.5539/jas.v11n1p274
}

\begin{abstract}
Population growth and improved gross domestic product may increase food consumption. Soybean is the main source of protein, lipids and mineral salts for human and domestic animals' foods. Brazil is responsible of most of the soybeans produced in the world. However, soybean production in Tocantins/Brazil state caused a decrease in the Cerrado's biome. Therefore, the aim of this study was to evaluate the anthropic impact of planting of soybean on microbial and physical-chemical properties of Cerrado's soil. Soil samples were collected in three soybean farms (SF) of the Tocantins/Brazil state. They were collected in the soybean field, in native vegetation field, and in anthropogenic fragmentation area in the dry and wet seasons. The diversity of arbuscular mycorrhizal fungi (AMF) and nitrogen-fixing bacteria (NFB) were analyzed by denaturing gradient gel electrophoresis (DGGE). Regardless of the SF, physico-chemical indicators did not present significant differences between the seasons. The DGGE profiles of NFB and AMF genes were different between the soybean field and native vegetation field in both seasons. The viable cells counts and NFBs and AMFs diversity were influenced by the substitution of native vegetation for soybean. The increase of the agricultural production in Cerrado soil is worrisome, due to the endemic microorganisms that was observed in this study. In addition, anthropic action on the microbial community was more effective in the soybean field during the dry season, which showed the importance of maintaining an environmental reserve area within agricultural production units.
\end{abstract}

Keywords: environmental impacts, mycorrhizal, nitrogen-fixing bacteria, soil resistance, native vegetation

\section{Introduction}

World population in July 2017 was 7.55 billion inhabitants and in 2050 it will be about 10.00 billions (UFNPA/ONU, 2017). If this population grows in geometric progression, Malthusian theory, it has an annual growth rate of about 0.78 . This rate is higher in poor and developing countries than in developed countries. Therefore, the human population in poor and developing countries, between 2017 and 2030, will have an increase of 83 millions (UFNPA/ONU, 2017).

According to the World Bank, the gross domestic product (GDP) in 2018 will have an increase of $3.1 \%$ in the world and 4.5\% in developing countries (Exame Magazine, 2018). The GDP growth in developing countries may be due to commodities exports. Growths in population and further improvement in GDP may increase food consumption and subsequently increase planting of soybean. This commodity is the main source of protein, lipids and mineral salts of human and domestic animal foods.

Brazil is responsible of most of the soybeans produced in the world. The country has approximately 33.890 million hectares planted with soybean that represent the world largest area planted with this plant (Conab, 2018). The agricultural regions of Maranhão (MA), Tocantins (TO), Piauí (PI) and Bahia (BA) states, which it is known as MATOPIBA, has been responsible for a big part of the country's soybean production. The Tocantins state has about 1.3 million hectares of soybean that is the highest area of soybean planting among high altitude regions (SEAGRO, 2017). 
The soybean production in Tocantins state has caused a decrease of Cerrado biome in replacing native vegetation by soybean. This substitution may have changed the physical, chemical and biological properties of the soil, mainly in the agricultural layer. This layer houses microorganisms that degrade organic matter and rocks. Microbial decomposition of the rocks from the mineral soils of the Cerrado. Therefore, identification of these microorganisms is an important parameter to evaluate the changes caused in the soil fauna by the conversion of native vegetation to soybean field.

Thus, the aim of the study was to evaluate the anthropic impact of planting of soybean on microbial and physical-chemical properties of Cerrado soil in regions of Tocantins state in Brazil.

\section{Materials and Methods}

\subsection{Site Location and Characterization}

The study was carried out in three regions of Tocantins/Brazil State, the highest soybean (Glycine max (L.) Merril) producers, including (i) Central region, (ii) Throat region and (iii) Campos Lindos and Petro Afonso region. The cities concerned per region were Porto Nacional, Silvanópolis and Santa Rosa in the Central region and Mateiros and Dianópolis in the Throat region (Table 1). The climate, soil, and vegetation are peculiar to the region (Table 1).

Table 1. Climate, soil declivity, vegetation and soil type of the Tocantins/Brazil state for collection of soil samples

\begin{tabular}{|c|c|c|c|c|c|}
\hline Tocantins/Brazil regions & Cities & Climate & Declivity & Soil & Phytoecology \\
\hline \multirow{3}{*}{ Central } & Porto Nacional & \multirow{6}{*}{$\begin{array}{l}\text { C2wA'a", } \\
\text { (Humid and subhumid } \\
\text { with moderate } \\
\text { water deficiency) }\end{array}$} & \multirow{6}{*}{$\begin{array}{l}\text { Class A } \\
(<5 \%)\end{array}$} & & \multirow{8}{*}{$\begin{array}{l}\text { Cerrado biome } \\
\text { Ecological Pressure } \\
\text { (Disjunction Cerrado/ } \\
\text { Seasonal Forest }\end{array}$} \\
\hline & Silvanónolis & & & Latosol & \\
\hline & Silvanopolis & & & Plintosols & \\
\hline \multirow{2}{*}{ Campos Lindos and Pedro Afonso } & Santa Rosa & & & Neosol & \\
\hline & & & & Latosol & \\
\hline \multirow[b]{3}{*}{ Throat } & Mateiros & & & Neosol & \\
\hline & & C2w2A'a' & & & \\
\hline & Dianópolis & $\begin{array}{l}\text { (Humid and subhumid } \\
\text { with small } \\
\text { water deficiency) }\end{array}$ & $\begin{array}{l}\text { Classe C } \\
(10-15 \%)\end{array}$ & Cambisol Neosol & \\
\hline
\end{tabular}

Source: Tocantins atlas (2012).

\subsection{Sample Collection Plan}

The soil samples were obtained in three soybean farms (SF) of the Tocantins/Brazil. They were collected in three different areas of soybean planting or native vegetation and four sampling points (Table 1).

In the Throat region (SF1), soil samples were collected in (i) the soybean field, (ii) in the native vegetation of Serra Geral field, and (iii) in the native vegetation field adjacent to the soybean field.

In Pedro Afonso/Tocantins/Brazil city (SF2), soil samples were collected in (i) one soybean field with little dead plant cover (soybean field 1), (ii) one native vegetation field of an ephemeral stream, surrounded by soybean field, and (iii) one soybean field with moderate dead plant cover (soybean field 2). The soybean fields 1 and 2 had about three years of cultivation of the crop. The soils were light gray and red-yellow, respectively. In the native vegetation, the relief was uneven and gravelly.

In the Central region (SF3), soil samples were collected in (i) one area of crop-livestock system integrating a beef cattle herd and soybean cultivation (soybean field), (ii) one native vegetation field, and (iii) one anthropogenic fragmentation area. The soil in this area had little dead vegetation cover, red-yellow color and enough gravel on the surface and along the profile. In points, P25-P26 has also invasive plants (Tables 2 to 5). The native vegetation area had foliage on the soil surface, plenty of gravel, adventitious roots and a natural runoff of water. The anthropogenic fragmentation area that is an island in the soybean field has dark red soil, arboreal vegetation of 15 to $20 \mathrm{~m}$ tall, abundant foliage on the surface and adventitious roots along the soil profile.

The soil samples were collected in 0 to 10,10 to 20,20 to 30 and 90 to $100 \mathrm{~cm}$ of depths in the dry period of September 2016 and wet period of January 2017. At each depth, three samples $(10 \mathrm{~g})$ were collected using a Dutch auger, according to the methodology of Raij (2001). The depth of $0-30 \mathrm{~cm}$ was defined as the effective 
depth for soybean roots $(\sim 40 \mathrm{~cm})$. The $90-100 \mathrm{~cm}$ depth was used to analyze the leaching effect of chemical elements from fertilizers and agrochemicals. In these soil samples were assessed the physical-chemical indicators and microbiota soil (item 2.4). The physico-chemical indicators were determined according to Standard Methods (APHA, 2005). Soil resistance to root penetration in depths of 0 to $60 \mathrm{~cm}$ and $2.5 \mathrm{~cm}$ interval was measured with the aid of a penetrometer (Falker-PLG 1020).

\subsection{Analysis of the Soil Microbiota in the Dry and Wet Seasons}

These analyses were performed as described in Carvalho et al. (2018).

\subsubsection{Viable Microbial Cells in Soil}

Ten grams of soil sample were used to quantify the viable microorganisms. The quantification of bacterial cell was performed in the nutrient agar culture medium containing $0.3 \mathrm{ml}$ of nystatin at $\mathrm{pH} 7$ (Sabino, 2007). The plates were incubated at $25^{\circ} \mathrm{C}$ for 3 days.

Martin medium containing rose bengal $(0.1 \% \mathrm{w} / \mathrm{v})$ and $1 \mathrm{ml}$ of streptomycin $(0.3 \mathrm{mg} / \mathrm{ml})$ was used to filamentous fungi count (Martin, 1950). The $\mathrm{pH}$ of this culture medium was $\mathrm{pH} 5.8$. The plates were incubated at $25^{\circ} \mathrm{C}$ for 7 days.

The actinomycete counts in selective medium containing glycerol (Rodrigues, 2007). The plates were incubated at $25^{\circ} \mathrm{C}$ for 7 days.

The microbial cells were estimated as logarithm of the colony-forming unit (CFU) per gram of soil.

\subsubsection{Microbial Diversity by DGGE Profile}

The diversity of arbuscular mycorrhizal fungi (AMF) and nitrogen-fixing bacteria (NFB) were analyzed by denaturing gradient gel electrophoresis (DGGE). Fungal and bacterial DNA were extracted from the soil samples using a soil DNA Mega Prep Kit (Kit-MO BIO, Ultraclean TM, Quiagen, USA). This extraction was done with $0.5 \mathrm{~g}$ of soil in plastic tubes (Eppendorf type) containing polypropylene beads. The nifH and $18 S \mathrm{rDNA}$ genes amplification were performed by polymerase chain reaction (PCR) from the total DNA for analysis of NFB and AMF, respectively.

The PCR and Nested-PCR of the nifH gene were done with the 19F and 407R primers (Ueda et al., 1995) and 19F-GC (with GC clamp) and 278R primers (Direito \& Teixeira, 2002), respectively. The 18S rDNA gene amplification was performed with AM1, NS31, NS31-GC (with GC clamp) and Glo1 primers (Simon et al., 1992; Helgason et al., 1998; Kowalchuk et al., 2002; Cornejo et al., 2004).

DGGE analysis of the Nested-PCR fragments was performed (Model DCodeTM Systems-BIO-RAD, California, USA). Twenty $\mu \mathrm{L}$ of these fragments (150 to $200 \mathrm{ng}$ of DNA) were loaded onto polyacrylamide gel $(8 \%, w / v)$ in 1 xTAE buffer.

\subsection{Statistical Analysis}

The estimates of the physical-chemical and biological parameters were performed at $95 \%$ confidence level $(\mathrm{p}<$ 0.05 ) based on the coefficient of variation (CV). Pimentel-Gomes (2000) classifies the experimental variations in low variation $(\mathrm{CV}<10 \%)$, medium $(10-20 \%)$, high $(20-30 \%)$, and very high $(\mathrm{CV}>30 \%)$.

The DGGE profiles were analyzed in the Bionumerics software Version 5.1 (Applied Maths, Belgium). The software has generated dendrograms of the unweighted pair group method with arithmetic mean (UPGMA) using the Jaccard similarity index. The similarity of bands was determined at $0.5 \%$ probability by the post-hoc Bonferroni test.

Excel, Surfer, SigmaPLOT12.0 and Minitab 17 software were also used in these analyses.

\section{Results and Discussions}

\subsection{Physical-Chemical Indicators Determination of Soil Quality}

We did not observe any difference in the physico-chemical indicators between seasons in the soybean farms (Figure 1).

In $\mathrm{SF}$ 1, differences were observed in the $\mathrm{Fe}, \mathrm{K}$ and $\mathrm{P}$ contents, base saturation, aluminum saturation and sand between sample collection points and soil depths (Figures 1A and 1B). These physico-chemical indicators and Mn content and clay had also no difference among the soil depths, soil moisture and samples collection points of SF2 (Figures 1C and 1D). In SF3, only Fe and K contents, organic matter, base saturation were different between soil depths and between sample collection points. Thus, although SF2 is closer to SF3 than to SF1, its 
physico-chemical indicators of this farm were similar to those of SF1 (Figure 1). Furthermore, we did not observe any difference in the physico-chemical indicators between seasons in the soybean farms (Figure 1).

In SF3, it was observed the anthropic influence on the physico-chemical indicators (Figure 2C). In addition, between the soybean field and the native vegetation field differed for $\mathrm{Fe}$ and $\mathrm{K}$ contents (Figure 2). These results showed the importance of maintaining an area with native vegetation cover within soybean farms.
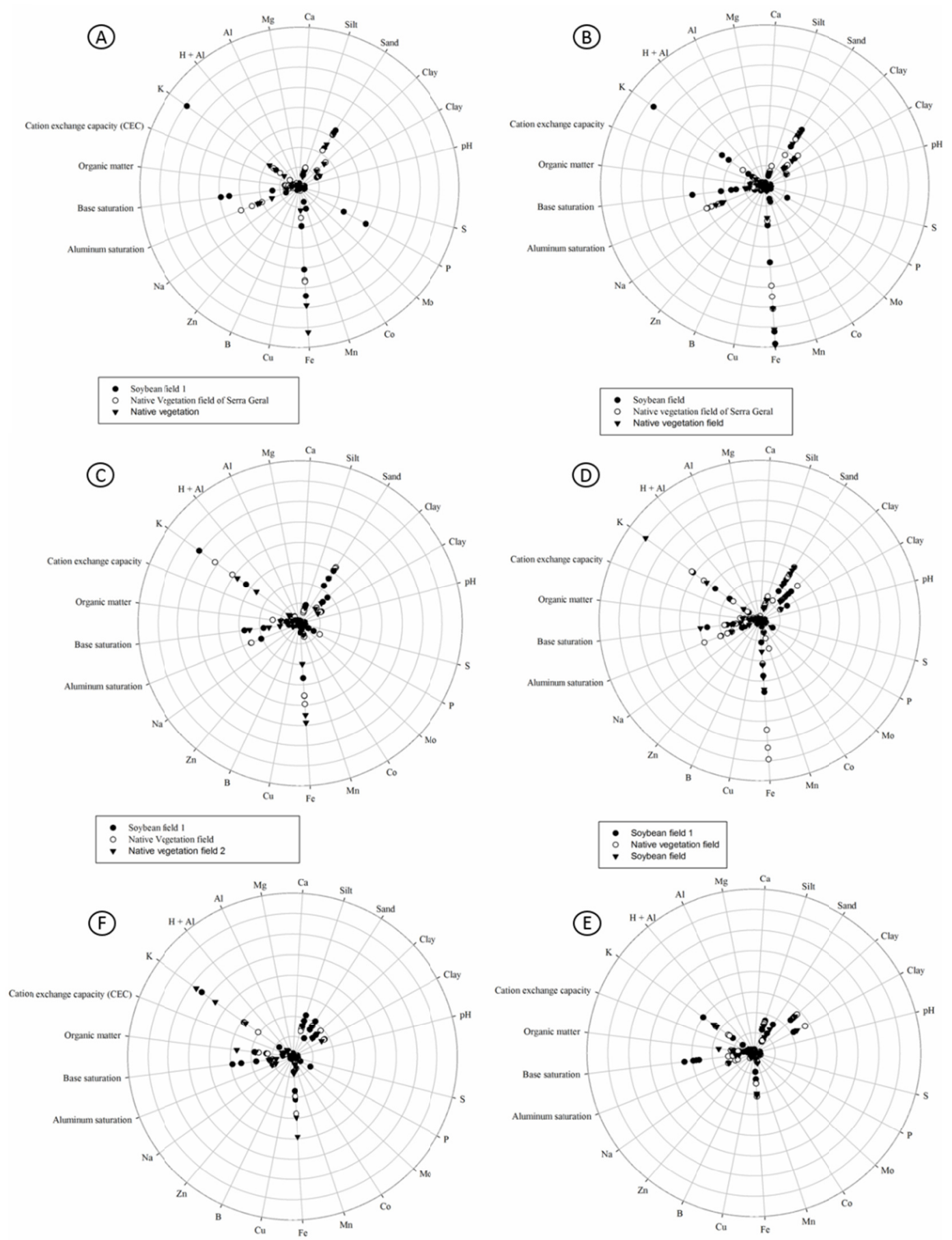

- Soybcan ficla 1

Native vegetation field

- Soybean field 1

Native vegetation field
Anthropogenic frazmentuation area

Figure 1. Physico-chemical indicators of soil in the soybean farms, SF1 (A and B), SF2 (C and D) and SF3 (E and F), in dry (A, C and E) and wet (B, D and F) seasons and soil depths of 0-10, 20-30, 30-40 plus 90-100 cm. 
The depth of 90-100 was performed only for the wet season, due to high resistance to soil penetration in dry season

\subsection{Resistance to Soybean Roots Penetration}

The resistance to root penetration (RP) in the three farms was measured under two soil moisture conditions (Figure 2). Plant growth has a negative correlation with soil compaction. The resistance to root penetration is the most used soil physical indicator to evaluate this condition (Beulter \& Centurion, 2004).
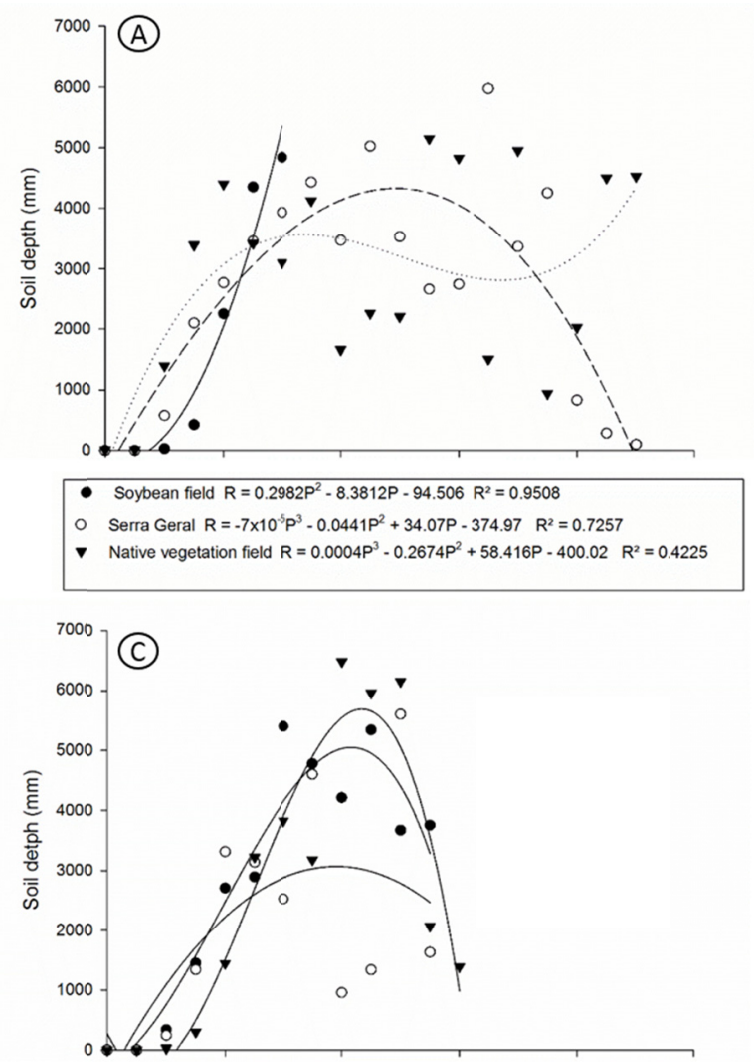

- Soybean field $1 \quad R=-0.001 P^{3}+0.2842 P^{2}+8.8477 P-273.01 \quad R^{2}=0.9162$

Native vegetation field $R=0.000007 P^{4}-0.0038 P^{3}+0.5483 P^{2}+1.6556 P-225.46 R^{2}=0.4354$

V Soybean field $2 R=-0.0019 P^{3}+0.71 P^{2}-39.574 P+268 R^{2}=0,8849$

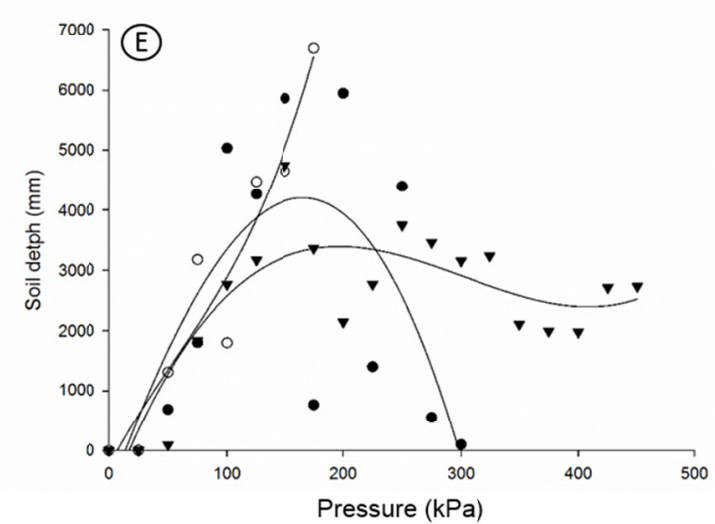

- Soybean field $1 R=-0.0000001 P^{5}+0.0001 P^{4}-0.0288 P^{3}+3.2115 P^{2}-83.846 P+98.413 R^{2}=0.5697$

- Native vegetation field $R=0.00003 P^{4} \cdot 0.0108 P^{3}+1.1214 P^{2}-5.6455 P-100.61 R^{2}=0.9244$

VAnthropogenic fragmentation area $R=2 \times 10^{-9} P^{4}+0.0003 P^{3}-0.2467 P^{2}+56.169 P-381.5 R^{i}=0.725$

Figure 2. Soil resistance to root penetration in soybean farms, SF1 (A and B), SF2 (C and D) and SF3 (E and F), during the dry (A, C and E) and wet (B, D and F) seasons
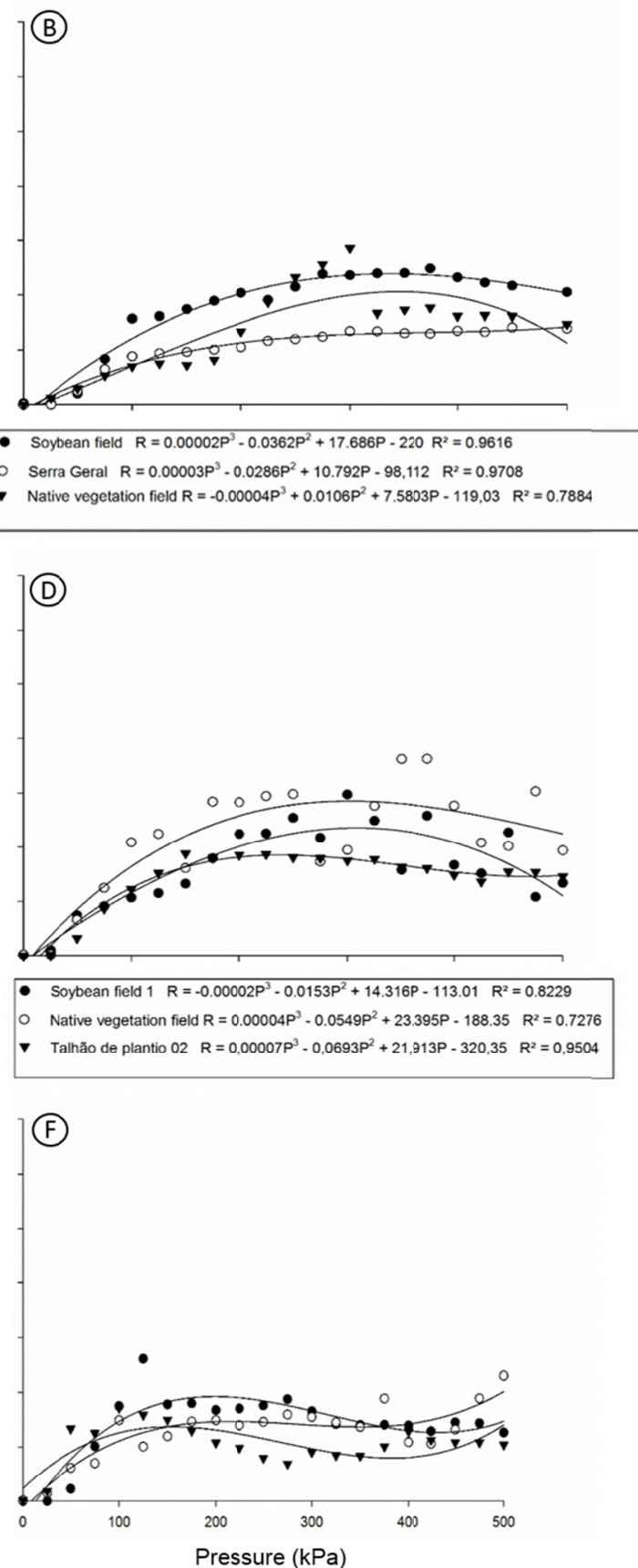

- Soybean field $1 R=0.0001 P^{3}-0.0989 P^{2}+26.92 P-338.59 R^{2}=0.7871$

- Native vegetation field $R=8 \times 10^{-5} P^{3}-0.0707 P^{2}+18.939 P-159.52 R^{2}=0.8127$

VAnthropogenic fragmentation area $R=0.0001 P^{3}-0.0776 P^{2}+17.062 P+233.54 R^{2}=0.5141$ 
The RP represent the critical limit of soil compaction (Figure 2). In soils of native vegetation has a roots depth threefold greater than in soil of soybean field, because of the reduction in RP and the increase of soil moisture (Genro Junior et al., 2004).

The soil of SF1 had RP of $2 \mathrm{MPa}$ in the dry season (Figure 2A). According to Tormena et al. (1998), this value is used as a critical limit to the soybean roots growth. The estimation of roots' depth in this area was higher than 50 $\mathrm{mm}$ in the dry season (Figures 2A and 2B).

In soybean field, the roots depth was higher than in other areas of SF1, because of the plowing and the harrowing that contributed to the reduction of RP by the breakdown of micro particles and increase of soil porosity. However, the removal of native vegetation and soil homogenization for soybean planting, might have contributed to increased soil moisture loss and RP if plowing and harrowing were not done.

\subsection{Biological Indicators of Soil Quality}

The biological indicators' estimation in soil samples did not concern samples collected from $90-100 \mathrm{~cm}$, because of small amount of microbial cell present at that depth. Carvalho et al. (2018) did not observed bands in the DGGE profile of NFB and AMF genes at this soil depth. According to the authors, there was no viable fungal cell in the soil at a depth beyond $30 \mathrm{~cm}$.

Viable bacterial cells counts were higher than those of actinomycete and fungi regardless of the soybean farm, sample collection points, soil depth, and season (Tables 3 to 5). These results are similar to those obtained by Silva et al. (2018) in soil samples from Cerrado. In addition, a high amount of actinomycete cells was observed in the farms. These microorganisms are mainly responsible of nitrogen fixation and its presence in the soybean field can reduce the requirement of nitrogen fertilization (Faleiro, 2011; Moreira \& Siqueira, 2006). Da Silva (2012) identified a predominance of the nifH gene in actinomycete when compared to other bacterial groups in Cerrado soil.

In both seasons, the DGGE profiles of NFB and AMF genes were different in soybean farms (Figures 3 to 5). The diversity of nifH gene in Cerrado soil was also changed by environmental conditions (Da Silva, 2012). The $18 S$ rDNA gene amplified using NS1 and FR1-GC primers presented alterations in the DGGE profile for different times of incubation (Gomes et al., 2003). NS1 primer was also used in this study to evaluate the AMFs diversity in soybean farm of the Tocantins state (Figures 3 to 5). Thus, the soybean farm had the different microbial diversity that shows the need for the preservation of Cerrado biome.

In these farms, bacterial diversity was greater than that of fungi, which confirms the results of viable cell counts (Tables 2 to 4) and Silva et al. (2018). This author analyzed the microbial communities in the soil with native vegetation cover. Furthermore, the soil microbial cell count may vary depending on the technique, the depth and the culture medium (Silva et al., 2018; Faleiro, 2011).

In SF1, the viable cell counts were lower in soybean field compared to native vegetation field (Table 2). This result showed the depressive effect of agricultural activity on the number of microbial cells that maight have affected their diversity in soybean fields. It was also observed that the microbial diversity of Serra Geral was intermediate between those of soybean field and native vegetation field. In the Serra Geral, human activities were greater than those observed in native vegetation field, which may have influenced in viable cell counts. The relative abundance of microorganisms in Cerrado soil after removal of native forest by anthropic activities has not been intensively studied (Monteiro et al., 2004). According to the authors, there are changes in the bacterial population after replacement the of native vegetation cover by planting of Eucalyptus and/or pinus.

The depth and moisture of soil had an unlike distinct influence on viable cell counts (Table 2). The counts were inversely proportional to soil depth. Monteiro et al. (2004) also observed this negative correlation between the microbial cell and soil depth. The fungal cell was not observed in the soil depth of 20-30 cm (Table 2). The cell count was higher in the wet season than the dry season that shows the influence of water availability on microbial growth. This increase of cell count in wet season may be due to spore germination or growth in size and number of cells favored by soil humidity. In fact, water is one of the parameters that most influence on microbial metabolism (Madigan et al., 2010 Tortora et al., 2014). Furthermore, in native vegetation field in the wet season, fungal cells were observed along the entire soil profile $(0-30 \mathrm{~cm})$. These fungal cells may be due to spore germination or cells percolation under moist condition. According to Gomes et al. (2003), fungi are in greatest quantity in the rhizosphere.

In SF1, the dry season's 16S-nifH profile differed from the wet season's one (Figure 3). In the dry season, bands from the same soil depth (SD1, SD2 and SD3) were grouped in the same cluster showing that bacterial distribution was a function of soil depth. 
Table 2. Viable microbial cells count in dry and wet seasons, of the soil samples of soybean farm 1 (SF1).

\begin{tabular}{|c|c|c|c|c|c|c|c|}
\hline \multirow{2}{*}{ Sampling area } & \multirow{2}{*}{ Sample code } & \multicolumn{3}{|c|}{ Dry season } & \multicolumn{3}{|c|}{ Wet season } \\
\hline & & Actinomycetes & Bacteria & Fungi & Actinomycetes & Bacteria & Fungi \\
\hline \multirow{13}{*}{ Soybean field } & & ----------------------- & --------------- & og (Colony & ming unit $\left.\mathrm{g}^{-1}\right)$ & -------------' & ------------- \\
\hline & P1SD1 & $7.73 \pm 0.22$ & $12.7 \pm 0.89$ & $6.27 \pm 0.25$ & $9.52 \pm 0.49$ & $13.29 \pm 0.40$ & $7.88 \pm 0.71$ \\
\hline & $\mathrm{P} 1 \mathrm{SD} 2$ & $6.22 \pm 0.10$ & $9.90 \pm 0.98$ & $5.08 \pm 0.20$ & $7.62 \pm 0.50$ & $10.85 \pm 0.38$ & $6.89 \pm 0.72$ \\
\hline & P1SD3 & $5.31 \pm 0.11$ & $7.80 \pm 0.90$ & & $6.47 \pm 0.51$ & $9.19 \pm 0.27$ & \\
\hline & P2SD1 & $9.39 \pm 0.11$ & $12.8 \pm 0.61$ & $7.76 \pm 0.24$ & $11.36 \pm 0.45$ & $13.10 \pm 0.47$ & $8.69 \pm 0.73$ \\
\hline & $\mathrm{P} 2 \mathrm{SD} 2$ & $8.31 \pm 0.11$ & $9.21 \pm 0.61$ & $5.62 \pm 0.20$ & $9.20 \pm 0.58$ & $10.20 \pm 0.41$ & $6.26 \pm 0.73$ \\
\hline & $\mathrm{P} 2 \mathrm{SD} 3$ & $6.11 \pm 0.11$ & $7.21 \pm 0.70$ & & $7.30 \pm 0.59$ & $9.56 \pm 0.30$ & \\
\hline & P3SD1 & $10.48 \pm 0.10$ & $13.1 \pm 0.65$ & $8.41 \pm 0.24$ & $12.44 \pm 0.54$ & $13.13 \pm 0.46$ & $8.82 \pm 0.74$ \\
\hline & P3SD2 & $7.54 \pm 0.10$ & $10.2 \pm 0.23$ & $6.54 \pm 0.26$ & $8.90 \pm 0.59$ & $10.82 \pm 0.37$ & $4.96 \pm 0.75$ \\
\hline & P3SD3 & $5.76 \pm 0.10$ & $8.71 \pm 0.27$ & & $6.75 \pm 0.55$ & $9.83 \pm 0.28$ & \\
\hline & P4SD1 & $10.82 \pm 0.10$ & $12.32 \pm 0.36$ & $8.35 \pm 0.22$ & $12.62 \pm 0.44$ & $13.89 \pm 0.39$ & $9.28 \pm 0.75$ \\
\hline & P4SD2 & $9.51 \pm 0.11$ & $10.63 \pm 0.39$ & $7.36 \pm 0.22$ & $10.03 \pm 0.10$ & $10.92 \pm 0.33$ & $6.79 \pm 0.76$ \\
\hline & P4SD3 & $7.89 \pm 0.11$ & $8.92 \pm 0.70$ & & $9.09 \pm 0.29$ & $9.87 \pm 0.27$ & \\
\hline \multirow{12}{*}{$\begin{array}{l}\text { Native vegetation } \\
\text { field of Serra Geral }\end{array}$} & P5SD1 & $10.38 \pm 0.10$ & $12.50 \pm 0.66$ & $8.71 \pm 0.24$ & $11.90 \pm 0.30$ & $13.06 \pm 0.44$ & $9.06 \pm 0.77$ \\
\hline & P5SD2 & $8.64 \pm 0.11$ & $10.10 \pm 0.28$ & $7.68 \pm 0.22$ & $9.84 \pm 0.30$ & $10.25 \pm 0.34$ & $7.58 \pm 0.77$ \\
\hline & P5SD3 & $5.91 \pm 0.11$ & $7.20 \pm 0.74$ & & $6.69 \pm 0.31$ & $9.06 \pm 0.28$ & \\
\hline & P6SD1 & $11.98 \pm 0.10$ & $13.0 \pm 0.55$ & $9.05 \pm 0.22$ & $12.49 \pm 0.32$ & $13.13 \pm 0.38$ & $9.81 \pm 0.78$ \\
\hline & $\mathrm{P} 6 \mathrm{SD} 2$ & $9.68 \pm 0.11$ & $10.20 \pm 0.49$ & $7.94 \pm 0.25$ & $9.84 \pm 0.32$ & $10.24 \pm 0.36$ & $8.64 \pm 0.79$ \\
\hline & P6SD3 & $7.25 \pm 0.10$ & $8.70 \pm 0.32$ & & $8.07 \pm 0.47$ & $9.42 \pm 0.28$ & \\
\hline & P7SD1 & $11.61 \pm 0.11$ & $13.20 \pm 0.98$ & $8.50 \pm 0.22$ & $11.85 \pm 0.45$ & $13.16 \pm 0.41$ & $9.26 \pm 0.79$ \\
\hline & $\mathrm{P} 7 \mathrm{SD} 2$ & $8.99 \pm 0.11$ & $10.10 \pm 0.70$ & $6.43 \pm 0.24$ & $9.90 \pm 0.46$ & $10.90 \pm 0.34$ & $8.17 \pm 0.80$ \\
\hline & P7SD3 & $6.43 \pm 0.11$ & $7.61 \pm 0.66$ & & $7.92 \pm 0.47$ & $9.48 \pm 0.29$ & \\
\hline & P8SD1 & $11.79 \pm 0.11$ & $13.41 \pm 0.43$ & $8.22 \pm 0.20$ & $12.44 \pm 0.49$ & $13.64 \pm 0.42$ & $9.62 \pm 0.73$ \\
\hline & P8SD2 & $10.57 \pm 0.11$ & $10.81 \pm 0.44$ & $5.95 \pm 0.24$ & $10.87 \pm 0.50$ & $11.72 \pm 0.34$ & $8.69 \pm 0.74$ \\
\hline & P8SD3 & $7.88 \pm 0.10$ & $8.32 \pm 0.37$ & & $9.54 \pm 0.46$ & $9.94 \pm 0.27$ & \\
\hline \multirow{12}{*}{ Native vegetation field } & P9SD1 & $11.83 \pm 0.11$ & $13.72 \pm 0.95$ & $8.38 \pm 0.25$ & $14.22 \pm 0.49$ & $14.67 \pm 0.42$ & $9.84 \pm 0.75$ \\
\hline & P9SD2 & $10.49 \pm 0.10$ & $11.12 \pm 0.47$ & $5.96 \pm 0.22$ & $11.53 \pm 0.45$ & $11.89 \pm 0.37$ & $6.78 \pm 0.75$ \\
\hline & P9SD3 & $8.24 \pm 0.11$ & $8.43 \pm 0.96$ & & $8.79 \pm 0.29$ & $8.97 \pm 0.29$ & $2.54 \pm 0.44$ \\
\hline & P10SD1 & $12.03 \pm 0.11$ & $13.51 \pm 0.63$ & $8.66 \pm 0.24$ & $13.20 \pm 0.30$ & $14.2 \pm 0.40$ & $9.51 \pm 0.76$ \\
\hline & P10SD2 & $10.26 \pm 0.11$ & $10.93 \pm 0.56$ & $7.35 \pm 0.22$ & $11.04 \pm 0.31$ & $11.32 \pm 0.30$ & $8.75 \pm 0.76$ \\
\hline & P10SD3 & $5.55 \pm 0.11$ & $8.20 \pm 0.47$ & & $6.98 \pm 0.31$ & $9.22 \pm 0.47$ & $2.68 \pm 0.34$ \\
\hline & P11SD1 & $12.49 \pm 0.11$ & $13.92 \pm 0.70$ & $8.58 \pm 0.25$ & $14.48 \pm 0.54$ & $14.51 \pm 0.70$ & $10.77 \pm 0.25$ \\
\hline & P11SD2 & $9.20 \pm 0.11$ & $10.93 \pm 0.70$ & $8.14 \pm 0.22$ & $10.91 \pm 0.55$ & $11.16 \pm 0.70$ & $9.72 \pm 0.22$ \\
\hline & P11SD3 & $6.46 \pm 0.11$ & $8.51 \pm 0.66$ & & $7.41 \pm 0.56$ & $9.45 \pm 0.66$ & $2.57 \pm 0.31$ \\
\hline & P12SD1 & $12.45 \pm 0.11$ & $13.40 \pm 0.28$ & $8.76 \pm 0.24$ & $14.21 \pm 0.11$ & $14.40 \pm 0.28$ & $10.92 \pm 0.24$ \\
\hline & P12SD2 & $9.62 \pm 0.11$ & $10.40 \pm 0.74$ & $8.70 \pm 0.22$ & $10.01 \pm 0.49$ & $11.44 \pm 0.74$ & $9.37 \pm 0.22$ \\
\hline & P12SD3 & $6.81 \pm 0.10$ & $8.72 \pm 0.55$ & & $7.90 \pm 0.32$ & $9.30 \pm 0.55$ & $2.64 \pm 0.32$ \\
\hline
\end{tabular}

Note. P: Sample collection point, SD: Soil depth (SD1 = 0-10, SD2 = 10-20, SD3 = 20-30 cm). 


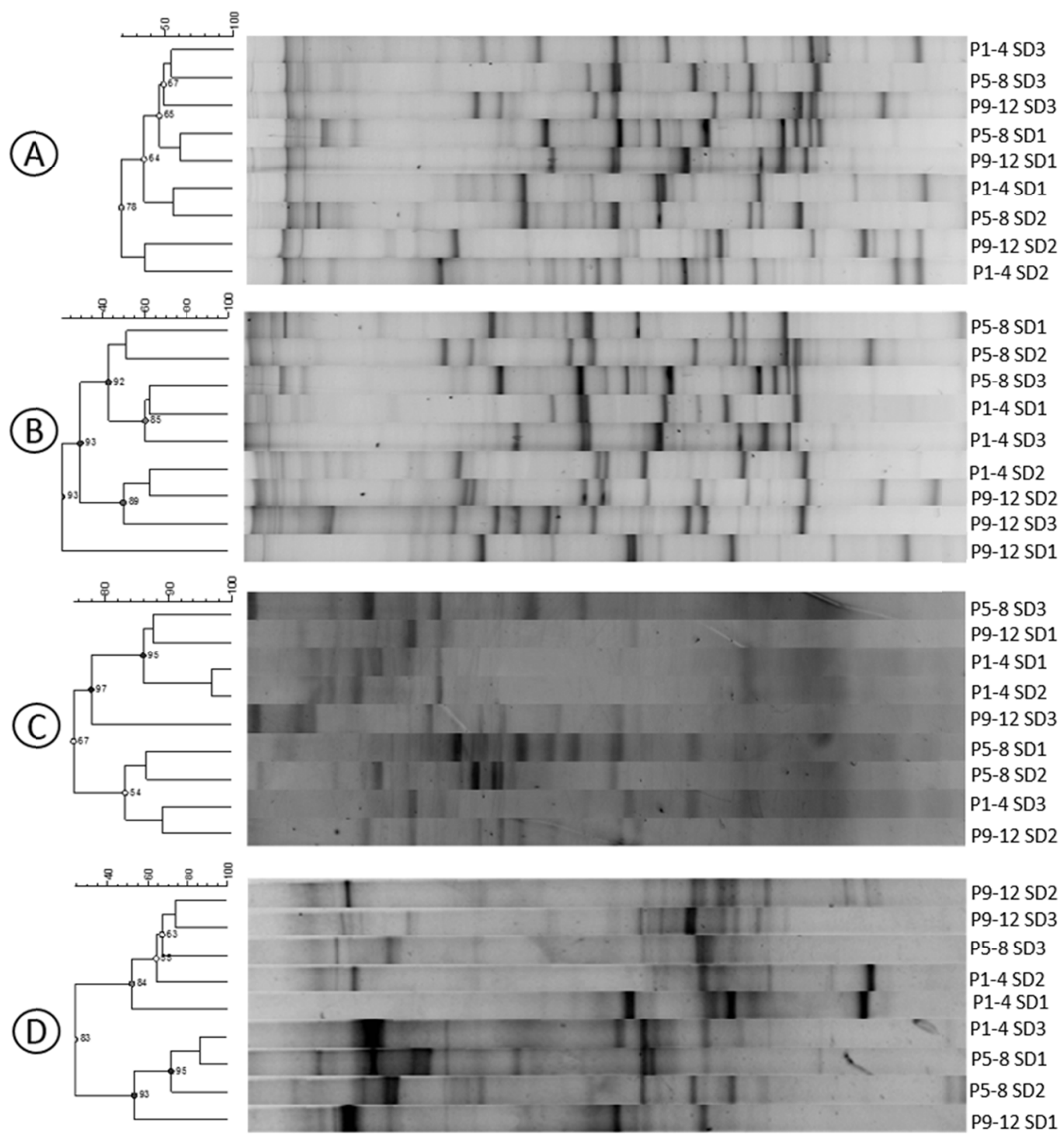

Figure 3. The DGGE profile of the $16 \mathrm{~S} r D N A$, nifH (A and B) and $18 S \mathrm{SDNA}$ and arbuscular mycorrhizal genes $(\mathrm{C}$ and $\mathrm{D})$ of soils from the soybean farm 1 in dry (A and $\mathrm{C}$ ) and wet (B and $\mathrm{D})$ seasons (Cf Table 2 for samples' codes)

On soil depth of $0-10 \mathrm{~cm}$ soil depth (SD1), there was $65 \%$ of similarity of bacterial communities between soybean field (P1-4), native vegetation field of Serra Geral (P5-8) and native vegetation field (E9-12). At 10-20 $\mathrm{cm}$ (SD2) and 20-30 cm (SD3), the similarities were $64 \%$ and $67 \%$, respectively. Therefore, the bacterial community of the native vegetation field was also found in the other areas that showed that the anthropic changes have not yet affected these bacterial groups.

In the wet season, bands clustered on the basis of the soil sampling points (Figure 3B). The areas of native vegetation had 89 and $85 \%$ of similarity for $16 \mathrm{~S}$-nifH bands in the three depth. These results show the influence of water infiltration on the bacterial community. This is to say that floods and infiltration had evenly distributed the bacteria communities along the soil profile.

The fungal community was similar in all areas points of samples collection of SF1, regardless of anthropic action and soil depth (Figures 3C and 3D). In the wet season, an increase in the intensity of the DGGE bands was observed (Figure 3D). This increase was proportional to the viable fungal cells amount. Barbosa (2014) also observed an increase in the number of DGGE bands and the fungal cells amount in the wet season.

In SF2, the viable microbial cell count was lower in the soybean field than in native vegetation field that showed once again the preservative action of native vegetation cover on the soil microbiota (Table 3). 
The effect of the moisture and depth of soil in SF2 on the viable cell count was similar to the results of SF1 (Table 3). In fact, the lowest count was at 20-30 cm depth and in the dry season. The fungal growth was limited in anoxic sites (Madigan et al., 2010, Tortora et al., 2014).

Table 3. Viable microbial cells count in dry and wet seasons, of the soil samples of soybean farm 2 (SF2)

\begin{tabular}{|c|c|c|c|c|c|c|c|}
\hline \multirow{2}{*}{ Sampling area } & \multirow{2}{*}{ Sample code } & \multicolumn{3}{|c|}{ Dry season } & \multicolumn{3}{|c|}{ Wet season } \\
\hline & & Actinomycete & Bacteria & Fungi & Actinomycete & Bacteria & Fungi \\
\hline \multirow{13}{*}{ Soybean field 1} & & 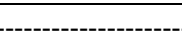 & (- & og (Colony & aing unit $\left.\mathrm{g}^{-1}\right)$-- & - & -------------- \\
\hline & P13SD1 & $7.47 \pm 0.45$ & $10.00 \pm 0.29$ & $6.18 \pm 0.32$ & $9.12 \pm 0.89$ & $12.20 \pm 0.42$ & $7.55 \pm 0.39$ \\
\hline & P13SD2 & $5.73 \pm 0.47$ & $8.20 \pm 0.31$ & $5.18 \pm 0.29$ & $6.95 \pm 0.95$ & $9.90 \pm 0.36$ & $6.29 \pm 0.33$ \\
\hline & P13SD3 & $4.01 \pm 0.48$ & $6.10 \pm 0.31$ & & $6.04 \pm 0.48$ & $7.30 \pm 0.52$ & \\
\hline & P14SD1 & $9.02 \pm 0.50$ & $10.90 \pm 0.32$ & $6.90 \pm 0.46$ & $10.82 \pm 0.61$ & $13.10 \pm 0.21$ & $8.28 \pm 0.31$ \\
\hline & P14SD2 & $8.54 \pm 0.45$ & $9.30 \pm 0.32$ & $6.29 \pm 0.49$ & $10.18 \pm 0.61$ & $11.10 \pm 0.45$ & $7.51 \pm 0.37$ \\
\hline & P14SD3 & $4.98 \pm 0.46$ & $7.50 \pm 0.32$ & & $7.09 \pm 0.70$ & $8.90 \pm 0.41$ & \\
\hline & P15SD1 & $10.10 \pm 0.46$ & $11.40 \pm 0.29$ & $6.83 \pm 0.30$ & $11.90 \pm 0.65$ & $13.40 \pm 0.58$ & $8.04 \pm 0.31$ \\
\hline & P15SD2 & $7.32 \pm 0.48$ & $9.20 \pm 0.30$ & $5.38 \pm 0.31$ & $8.57 \pm 0.23$ & $10.80 \pm 0.34$ & $6.30 \pm 0.33$ \\
\hline & P15SD3 & $4.79 \pm 0.49$ & $7.40 \pm 0.31$ & & $6.74 \pm 0.27$ & $8.70 \pm 0.31$ & \\
\hline & P16SD1 & $8.18 \pm 0.45$ & $9.90 \pm 0.31$ & $6.74 \pm 0.57$ & $11.78 \pm 0.36$ & $11.50 \pm 0.53$ & $7.79 \pm 0.11$ \\
\hline & P16SD2 & $6.96 \pm 0.47$ & $8.60 \pm 0.32$ & $5.98 \pm 0.59$ & $10.31 \pm 0.39$ & $9.90 \pm 0.59$ & $6.88 \pm 0.12$ \\
\hline & P16SD3 & $4.89 \pm 0.49$ & $7.70 \pm 0.32$ & & $9.02 \pm 0.70$ & $8.80 \pm 0.27$ & $2.77 \pm 0.80$ \\
\hline \multirow{12}{*}{$\begin{array}{l}\text { Native vegetation field } \\
\text { of ephemeral stream }\end{array}$} & P17SD1 & $11.36 \pm 0.47$ & $12.60 \pm 0.30$ & $6.69 \pm 0.56$ & $13.63 \pm 0.47$ & $14.10 \pm 0.58$ & $8.03 \pm 0.06$ \\
\hline & P17SD2 & $9.80 \pm 0.48$ & $10.30 \pm 0.31$ & $6.23 \pm 0.56$ & $11.69 \pm 0.96$ & $12.20 \pm 0.45$ & $7.42 \pm 0.60$ \\
\hline & P17SD3 & $5.51 \pm 0.49$ & $8.20 \pm 0.31$ & & $10.08 \pm 0.62$ & $9.70 \pm 0.50$ & \\
\hline & P18SD1 & $11.48 \pm 0.46$ & $11.70 \pm 0.32$ & $6.99 \pm 0.30$ & $13.52 \pm 0.56$ & $13.80 \pm 0.48$ & $8.24 \pm 0.26$ \\
\hline & P18SD2 & $7.55 \pm 0.46$ & $8.60 \pm 0.32$ & $5.83 \pm 0.48$ & $11.19 \pm 0.47$ & $10.10 \pm 0.47$ & $6.82 \pm 0.30$ \\
\hline & P18SD3 & $5.60 \pm 0.49$ & $8.00 \pm 0.30$ & & $10.01 \pm 0.70$ & $9.30 \pm 0.52$ & \\
\hline & P19SD1 & $10.99 \pm 0.50$ & $11.70 \pm 0.31$ & $7.10 \pm 0.49$ & $13.88 \pm 0.63$ & $13.60 \pm 0.47$ & $8.22 \pm 0.17$ \\
\hline & P19SD2 & $10.31 \pm 0.50$ & $10.50 \pm 0.49$ & $6.46 \pm 0.32$ & $11.80 \pm 0.39$ & $12.00 \pm 1.67$ & $7.43 \pm 0.09$ \\
\hline & P19SD3 & $5.00 \pm 0.45$ & $9.50 \pm 0.51$ & & $6.90 \pm 0.47$ & $10.90 \pm 0.94$ & \\
\hline & P20SD1 & $11.91 \pm 0.46$ & $12.30 \pm 0.46$ & $7.34 \pm 0.31$ & $13.50 \pm 0.74$ & $14.00 \pm 0.40$ & $8.34 \pm 0.23$ \\
\hline & P20SD2 & $7.70 \pm 0.47$ & $9.00 \pm 0.48$ & $6.99 \pm 0.46$ & $10.90 \pm 0.59$ & $10.10 \pm 0.47$ & $7.90 \pm 0.19$ \\
\hline & P20SD3 & $5.61 \pm 0.48$ & $8.30 \pm 0.32$ & & $9.60 \pm 0.81$ & $9.30 \pm 0.70$ & \\
\hline \multirow{12}{*}{ Soybean field 2} & P21SD1 & $9.72 \pm 0.50$ & $11.80 \pm 0.29$ & $7.11 \pm 0.48$ & $11.05 \pm 0.66$ & $13.50 \pm 0.35$ & $8.09 \pm 0.18$ \\
\hline & $\mathrm{P} 21 \mathrm{SD} 2$ & $7.94 \pm 0.45$ & $9.00 \pm 0.31$ & $6.19 \pm 0.49$ & $8.97 \pm 0.74$ & $10.10 \pm 0.40$ & $7.00 \pm 0.15$ \\
\hline & P21SD3 & $4.69 \pm 0.46$ & $7.80 \pm 0.31$ & & $6.40 \pm 0.55$ & $8.80 \pm 0.45$ & \\
\hline & P22SD1 & $9.27 \pm 0.48$ & $10.80 \pm 0.32$ & $7.56 \pm 0.58$ & $12.59 \pm 0.49$ & $12.10 \pm 0.72$ & $8.44 \pm 0.15$ \\
\hline & P22SD2 & $9.35 \pm 0.49$ & $10.50 \pm 0.29$ & $6.85 \pm 0.56$ & $10.38 \pm 0.32$ & $11.70 \pm 0.66$ & $7.61 \pm 0.95$ \\
\hline & P22SD3 & $4.50 \pm 0.46$ & $8.20 \pm 0.30$ & & $9.40 \pm 0.98$ & $9.00 \pm 0.90$ & \\
\hline & P23SD1 & $10.93 \pm 0.49$ & $12.00 \pm 0.31$ & $7.23 \pm 0.60$ & $12.01 \pm 0.70$ & $13.20 \pm 0.63$ & $7.95 \pm 0.17$ \\
\hline & $\mathrm{P} 23 \mathrm{SD} 2$ & $8.63 \pm 0.50$ & $10.50 \pm 0.31$ & $5.60 \pm 0.54$ & $9.42 \pm 0.66$ & $11.50 \pm 0.39$ & $6.12 \pm 0.09$ \\
\hline & P23SD3 & $4.77 \pm 0.51$ & $8.20 \pm 0.32$ & & $7.36 \pm 0.43$ & $8.90 \pm 0.47$ & \\
\hline & P24SD1 & $10.77 \pm 0.45$ & $10.80 \pm 0.32$ & $6.13 \pm 0.54$ & $13.16 \pm 0.44$ & $13.20 \pm 0.74$ & $7.50 \pm 0.23$ \\
\hline & P24SD2 & $8.13 \pm 0.46$ & $9.30 \pm 0.29$ & $4.68 \pm 0.57$ & $12.30 \pm 0.37$ & $11.30 \pm 0.59$ & $5.68 \pm 0.19$ \\
\hline & P24SD3 & $5.92 \pm 0.46$ & $7.20 \pm 0.29$ & & $10.76 \pm 0.95$ & $8.70 \pm 0.81$ & \\
\hline
\end{tabular}

Note. P: Sample collection point, SD: Soil depth (SD1 = 0-10, SD2 = 10-20, SD3 = 20-30 cm).

The viable microbial cell counts in soybean field 2 were similar to the cell counts from native vegetation field of the ephemeral stream (Table 3). This result may be due to the time of planting soybean and soil type. 
In SF2, we also observed that the NFBs and AMFs profiles depended on the season (Figure 4). Similar to the result of SF1, in the dry season, samples formed clusters for 16S-nifH gene based on soil depth (Figure 4A). Therefore, in same soil depth, there was no difference in microbial diversity among soybean field 1 (P13-16), native vegetation field (P17-20) and soybean field 2 (E21-24). This result may be due to the few microbial groups that can grow in low water availability. Silva et al. (2018) also obtained clusters of nifH and $18 S$ rDNA genes by soil depth in the Cerrado.

In the wet season, there was an increase in the intensity of $16 \mathrm{~S}$-nifH bands (Figure 4B). These bands were more evident in the upper part of the gel. Therefore, there was not an increase in bacterial diversity. Furthermore, only on the soil surface, there was a cluster between sample collection points, because of the influence of water on the microbial community.

In SF2, the bacterial community of native vegetation field was similar to the soybean field (Figures 4A and 4B). The soil resilience and the short time anthropic activity had not considerably affected bacteria in the soybean field.

The fungal community was present in all sample collection points, but with higher intensity in the wet season (Figures 4C and 4D). In dry season, there was no difference between bands of AMFs profile from 20-30 cm soil depth (Figure 4C). At this depth, the lack of oxygen and other nutrients led to low survival of the aerobic microorganisms. In addition, in the wet season, there was an increase in the intensity of the AMF bands (Figure 4D). Therefore, the highest fungal cell amount in the wet season was due to the water availability that contributes to spore germination. 

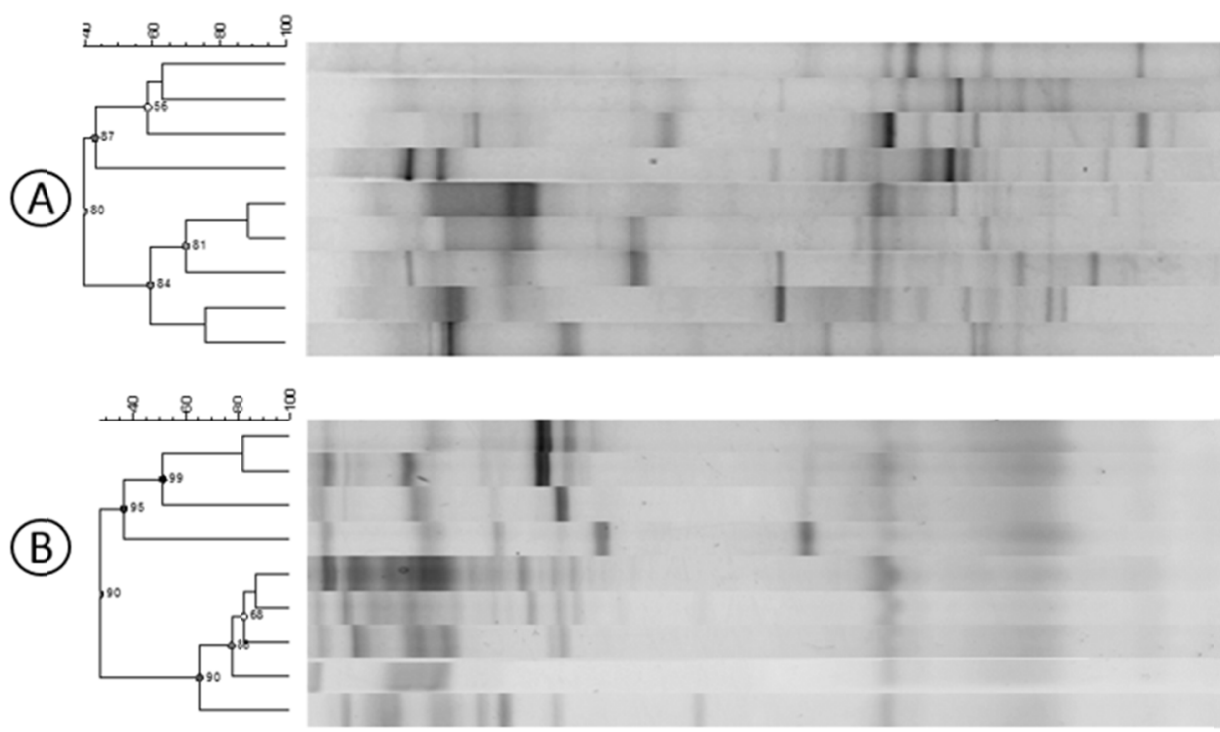

P21-24 SD3
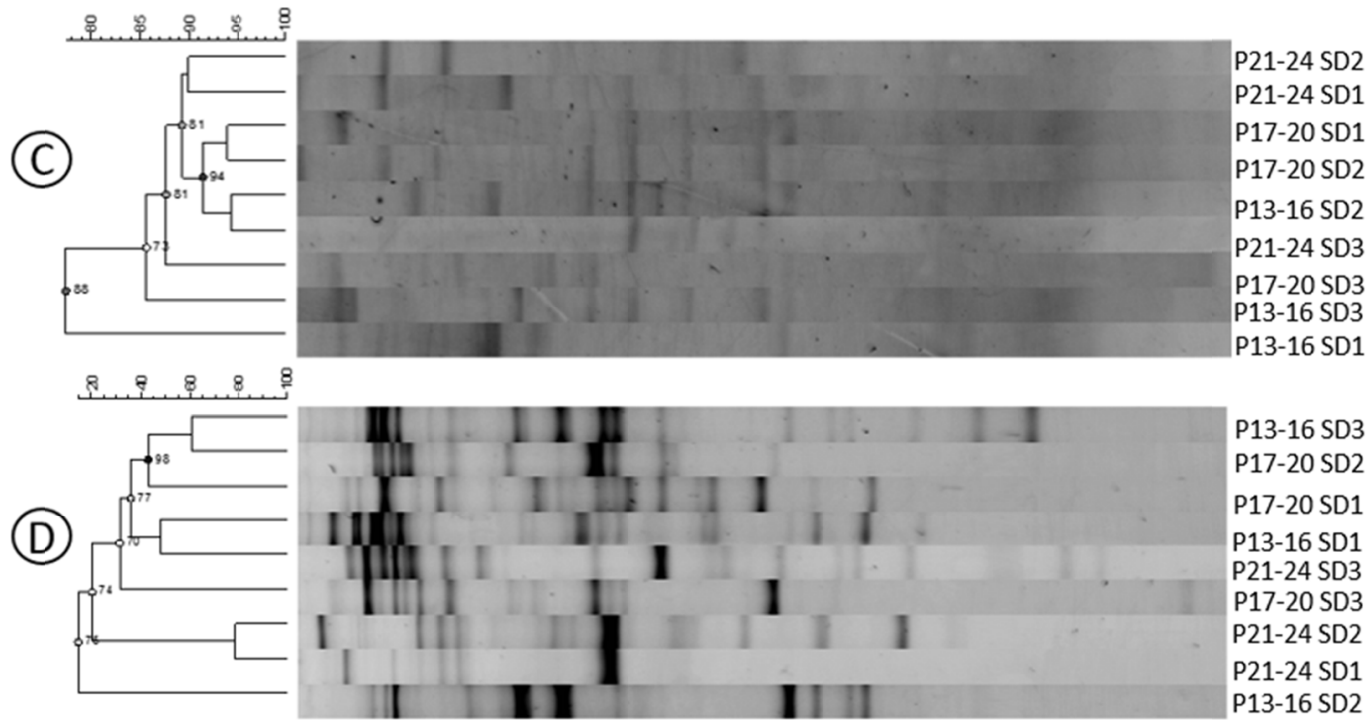

P13-16 SD3

P17-20 SD2

P17-20 SD1

P13-16 SD1

P21-24 SD3

P17-20 SD3

P21-24 SD2

P21-24 SD1

P13-16 SD2

Figure 4. DGGE profiles of the $16 S r D N A$, nifH (A and B) and $18 S$ rDNA and arbuscular mycorrhizal genes (C and $\mathrm{D}$ ) of soil from the soybean farm 2 in $\operatorname{dry}(\mathrm{A}$ and $\mathrm{C})$ and wet (B and D) seasons

(Cf table 4 for samples' codes)

In SF3, viable microbial cell counts were higher in native vegetation field than in soybean field and anthropogenic fragmentation (Table 4). In the anthropogenic fragmentation area, the cell count was the lowest due to soil compaction and disposal of food residues and others human utensils. In fact, the anthropogenic fragmentation area was the place of food residues disposal, of rest and sanitation of the rural workers. Food residues may have influenced the growth of fungi in 20-30 cm depth layer. These results show the importance of delimiting environmental preservation areas within of the soybean field.

The effect of depth and moisture soil on the quantity of microbial cells in SF3 was similar to the one observed in the others soybean farms (SF1 and SF2) (Tables 2 to 4). SF3 had the highest endemism rate showing profile of NFBs and AMFs different from those obtained from the other soybean farms (Figures 3 to 5). Furthermore, some bands of $16 \mathrm{~S}-$ nifH gene profile of soybean field were not found in native vegetation field and anthropic fragmentation DGGE profiles (Figure 5A). These results reinforce the need for an environmental preservation policy in this soybean farm.

In SF3, an increase in the number of bands of $16 \mathrm{~S}$-nifH gene was also observed in the wet season (Figure 5B). In the dry season, the 16S-nifH gene clustering by the soil depth (and sample collection points. The clustering for $16 \mathrm{~S}$-nifH gene was only a function the sample collection points in the wet season (Figures 5A and 5B). 
Table 4. Count of viable microbial cells in dry and wet seasons, of the soil samples of soybean farm 3 (SF3)

\begin{tabular}{|c|c|c|c|c|c|c|c|}
\hline \multirow{2}{*}{ Sampling area } & \multirow{2}{*}{ Sample code } & \multicolumn{3}{|c|}{ Dry season } & \multicolumn{3}{|c|}{ Wet season } \\
\hline & & Actinomycetes & Bacteria & Fungi & Actinomycetes & Bacteria & Fungi \\
\hline \multirow{13}{*}{ Soybean field 01} & & -------------------- & 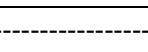 & Log (Colony & ming unit $\left.\mathrm{g}^{-1}\right)$ & - & - \\
\hline & P25SD1 & $6.59 \pm 0.29$ & $10.80 \pm 0.42$ & $5.45 \pm 0.17$ & $8.06 \pm 0.23$ & $13.17 \pm 0.45$ & $6.66 \pm 0.85$ \\
\hline & $\mathrm{P} 25 \mathrm{SD} 2$ & $4.90 \pm 0.28$ & $8.50 \pm 0.40$ & $4.43 \pm 0.17$ & $5.95 \pm 0.08$ & $10.31 \pm 0.36$ & $5.38 \pm 0.69$ \\
\hline & P25SD3 & $3.95 \pm 0.26$ & $5.80 \pm 0.37$ & & $4.76 \pm 0.27$ & $6.96 \pm 0.78$ & \\
\hline & P26SD1 & $8.01 \pm 0.29$ & $11.70 \pm 0.42$ & $6.13 \pm 0.17$ & $9.61 \pm 0.56$ & $13.99 \pm 0.51$ & $7.35 \pm 0.95$ \\
\hline & P26SD2 & $7.30 \pm 0.28$ & $9.50 \pm 0.40$ & $5.38 \pm 0.17$ & $8.70 \pm 0.73$ & $11.34 \pm 0.45$ & $6.42 \pm 0.83$ \\
\hline & P26SD3 & $4.71 \pm 0.26$ & $7.00 \pm 0.37$ & & $5.58 \pm 0.31$ & $8.30 \pm 0.69$ & \\
\hline & $\mathrm{P} 27 \mathrm{SD} 1$ & $8.92 \pm 0.29$ & $11.90 \pm 0.42$ & $6.0 \pm 0.17$ & $10.50 \pm 0.85$ & $13.99 \pm 0.51$ & $7.10 \pm 0.93$ \\
\hline & $\mathrm{P} 27 \mathrm{SD} 2$ & $6.26 \pm 0.28$ & $9.30 \pm 0.40$ & $4.6 \pm 0.17$ & $7.33 \pm 0.43$ & $10.84 \pm 0.39$ & $5.39 \pm 0.71$ \\
\hline & P27SD3 & $4.56 \pm 0.26$ & $6.80 \pm 0.37$ & & $5.31 \pm 0.30$ & $7.94 \pm 0.54$ & \\
\hline & P28SD1 & $9.04 \pm 0.29$ & $10.20 \pm 0.42$ & $5.98 \pm 0.17$ & $10.46 \pm 0.49$ & $11.82 \pm 0.52$ & $6.92 \pm 0.93$ \\
\hline & P28SD2 & $7.66 \pm 0.28$ & $8.50 \pm 0.40$ & $5.11 \pm 0.17$ & $8.82 \pm 0.44$ & $9.78 \pm 0.44$ & $5.88 \pm 0.79$ \\
\hline & P28SD3 & $6.22 \pm 0.26$ & $6.90 \pm 0.37$ & $1.57 \pm 0.15$ & $7.11 \pm 0.84$ & $7.92 \pm 0.14$ & $1.79 \pm 0.24$ \\
\hline \multirow{12}{*}{ Native vegetation field } & P29SD1 & $9.55 \pm 0.32$ & $13.20 \pm 0.46$ & $6.99 \pm 0.19$ & $10.86 \pm 0.84$ & $15.05 \pm 0.61$ & $7.95 \pm 0.88$ \\
\hline & P29SD2 & $7.58 \pm 0.31$ & $9.70 \pm 0.45$ & $5.92 \pm 0.19$ & $8.57 \pm 0.81$ & $10.95 \pm 0.52$ & $6.69 \pm 0.92$ \\
\hline & P29SD3 & $5.05 \pm 0.29$ & $7.80 \pm 0.42$ & $1.58 \pm 0.17$ & $5.68 \pm 0.31$ & $8.76 \pm 0.14$ & $1.78 \pm 0.25$ \\
\hline & P30SD1 & $11.25 \pm 0.33$ & $12.10 \pm 0.47$ & $7.55 \pm 0.20$ & $12.58 \pm 0.92$ & $13.51 \pm 0.68$ & $8.4 \pm 0.80$ \\
\hline & P30SD2 & $7.99 \pm 0.28$ & $10.00 \pm 0.40$ & $5.85 \pm 0.17$ & $8.88 \pm 0.89$ & $11.12 \pm 0.53$ & $6.51 \pm 0.91$ \\
\hline & P30SD3 & $6.70 \pm 0.26$ & $7.10 \pm 0.37$ & $1.82 \pm 0.15$ & $7.41 \pm 0.97$ & $7.86 \pm 0.16$ & $2.01 \pm 0.28$ \\
\hline & P31SD1 & $10.74 \pm 0.32$ & $13.00 \pm 0.46$ & $7.11 \pm 0.19$ & $11.81 \pm 0.81$ & $14.28 \pm 0.65$ & $7.81 \pm 1.10$ \\
\hline & P31SD2 & $7.55 \pm 0.29$ & $10.10 \pm 0.41$ & $4.90 \pm 0.17$ & $8.25 \pm 0.74$ & $11.02 \pm 0.45$ & $5.36 \pm 0.76$ \\
\hline & P31SD3 & $5.34 \pm 0.26$ & $7.00 \pm 0.37$ & $1.73 \pm 0.15$ & $5.80 \pm 0.54$ & $7.65 \pm 0.16$ & $1.88 \pm 0.27$ \\
\hline & P32SD1 & $10.53 \pm 0.32$ & $12.90 \pm 0.46$ & $6.00 \pm 0.19$ & $12.87 \pm 0.88$ & $15.74 \pm 0.49$ & $7.33 \pm 0.93$ \\
\hline & $\mathrm{P} 32 \mathrm{SD} 2$ & $8.66 \pm 0.28$ & $9.7 \pm 0.40$ & $4.00 \pm 0.17$ & $10.52 \pm 0.66$ & $11.73 \pm 0.33$ & $4.86 \pm 0.62$ \\
\hline & P32SD3 & $7.03 \pm 0.26$ & $6.80 \pm 0.37$ & $1.87 \pm 0.15$ & $5.48 \pm 0.66$ & $8.24 \pm 0.15$ & $2.26 \pm 0.29$ \\
\hline \multirow{12}{*}{$\begin{array}{l}\text { Anthropogenic } \\
\text { fragmentation area }\end{array}$} & P33SD1 & $4.35 \pm 0.13$ & $5.40 \pm 0.18$ & $2.56 \pm 0.07$ & $5.22 \pm 0.48$ & $6.48 \pm 0.21$ & $3.07 \pm 0.40$ \\
\hline & P33SD2 & $2.50 \pm 0.08$ & $3.10 \pm 0.12$ & $1.59 \pm 0.05$ & $2.98 \pm 0.27$ & $3.73 \pm 0.13$ & $1.90 \pm 0.25$ \\
\hline & P33SD3 & $6.70 \pm 0.26$ & $7.70 \pm 0.37$ & $1.95 \pm 0.15$ & $7.94 \pm 0.86$ & $9.09 \pm 0.16$ & $2.32 \pm 0.30$ \\
\hline & P34SD1 & $4.46 \pm 0.13$ & $5.40 \pm 0.18$ & $2.72 \pm 0.08$ & $5.25 \pm 0.53$ & $6.32 \pm 0.23$ & $3.20 \pm 0.42$ \\
\hline & P34SD2 & $2.23 \pm 0.08$ & $2.40 \pm 0.11$ & $1.36 \pm 0.05$ & $2.61 \pm 0.32$ & $2.76 \pm 0.12$ & $1.59 \pm 0.21$ \\
\hline & P34SD3 & $6.78 \pm 0.26$ & $7.30 \pm 0.37$ & & $7.89 \pm 0.95$ & $8.55 \pm 0.14$ & \\
\hline & P35SD1 & $4.39 \pm 0.12$ & $5.00 \pm 0.17$ & $2.60 \pm 0.07$ & $5.08 \pm 0.58$ & $5.75 \pm 0.22$ & $3.01 \pm 0.40$ \\
\hline & P35SD2 & $2.50 \pm 0.08$ & $2.90 \pm 0.12$ & $1.58 \pm 0.05$ & $2.90 \pm 0.31$ & $3.39 \pm 0.14$ & $1.82 \pm 0.24$ \\
\hline & P35SD3 & $3.20 \pm 0.17$ & $5.80 \pm 0.25$ & & $3.70 \pm 0.04$ & $6.59 \pm 0.16$ & \\
\hline & P36SD1 & $3.70 \pm 0.10$ & $4.40 \pm 0.15$ & $2.28 \pm 0.06$ & $4.20 \pm 0.46$ & $4.95 \pm 0.20$ & $2.60 \pm 0.35$ \\
\hline & P36SD2 & $2.00 \pm 0.07$ & $2.10 \pm 0.10$ & $1.47 \pm 0.04$ & $2.30 \pm 0.30$ & $2.41 \pm 0.13$ & $1.66 \pm 0.23$ \\
\hline & P36SD3 & $5.80 \pm 0.22$ & $6.30 \pm 0.32$ & & $6.60 \pm 0.82$ & $7.11 \pm 0.55$ & \\
\hline
\end{tabular}

Note. P: Samples collection point, SD: Soil depth $(\mathrm{SD} 1=0-10, \mathrm{SD} 2=10-20, \mathrm{SD} 3=20-30 \mathrm{~cm})$.

SF3 bands' profiles of $18 S-A M F s$ gene were also different from the profiles of the other soybean farms (Figures 3 to 5). In the dry season, the band's profiles of anthropogenic fragmentation were more closer to the profile of the soybean field than to that of the native vegetation field (Figure 5C). However, in the wet season, an inversion occurs of this result (Figure 5D). This demonstrate that the anthropogenic action is most evident in the period of water scarcity. 


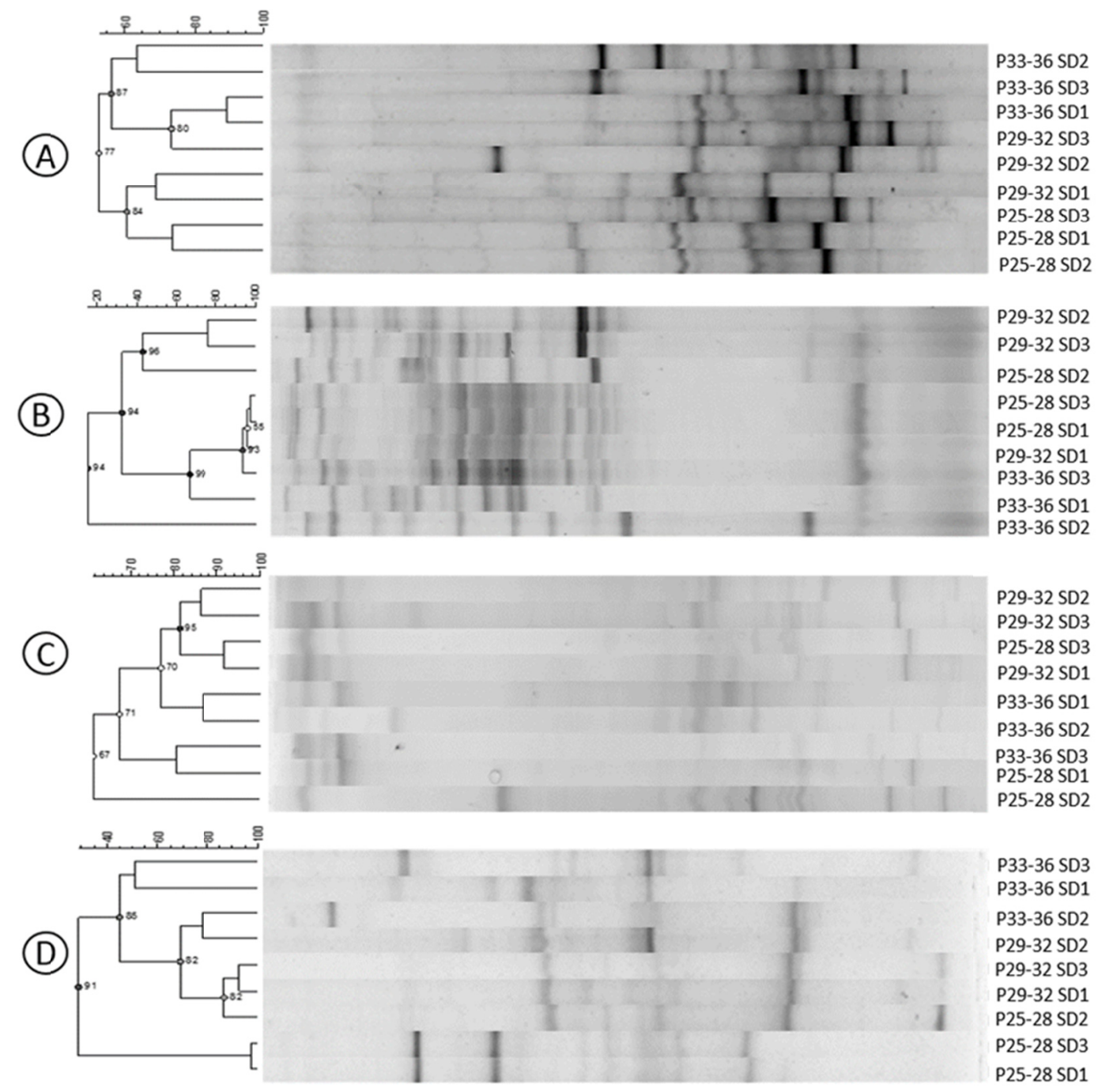

Figure 5. The DGGE profiles of the $16 S \mathrm{rDNA}$, nifH (A and B) and $18 S \mathrm{rDNA}$ and arbuscular mycorrhizal genes $(\mathrm{C}$ and $\mathrm{D})$ of soils from the soybean farm 2 in dry (A and C) and wet (B and D) seasons

(Cf Table 4 for samples' codes)

Thus, the DGGE profile of $18 S-A M F s$ was adequate to analyze differences in the AMF community before and after environmental changes. Vainio and Hantula (2000) also using the amplification of $18 S$ rDNA genes and NS1 primers for the study of the fungal community by DGGE showed that such amplification, have high-resolution bands. They concluded that DGGE is suitable for the detection of fungal groups under different crop and sampling conditions.

The increase of the agricultural production area in the Cerrado, especially in Porto Nacional/TO city is worrisome due to the endemic microorganisms rate that was observed in this study. Thus, the maintenance of areas with native vegetation cover is very important for the sustainability of agribusiness.

\section{Conclusion}

The average monthly temperature of the regions is not a limiting factor for soybean production; however, rainfall limits its cultivation from November to April. In these Cerrado regions, soils with native vegetation cover do not differ in dry and wet seasons, how much to the root growth. However, the removal of natural vegetation for soybean cultivation influences communities as well as NFBs and AMFs diversities. In addition, anthropic action on the microbial community is more effective in the period of water scarcity, which shows the importance of maintaining an environmental reserve area within agricultural production units. 


\section{Acknowledgements}

The authors are grateful for the financial, scientific and structural support of CNPQ, IFTO, BIONORTE, CEULP/ULBRA, UFV, and UFT. This study was financed in part by the Coordenação de Aperfeiçoamento de Pessoal de Nível Superior-Brasil (CAPES)-Finance Code 001.

\section{References}

APHA (American Public Health Association). (2005). Standard Methods for the Examination of Water and Wastewater (21st ed.). American Water Works Association (AWWA) \& Water Environment Federation (WEF).

Atlas do Tocantins. (2012). Subsídios ao planejamento da gestão territorial (6th ed.). Palmas: Seplan.

Barbosa, M. A. (2014). Caracterização molecular da microbiota em solos de restingaedunas com atividade de mineração no município de Mataraca, Paraíba, Brasil (p. 98). Universidade Federal de Pernambuco.

Bernardo, S., Soares, A. A., \& Mantovani, E. C. (2004). Manual de irrigação (8th ed., p. 625). Viçosa: UFV.

Beulter, A. N., \& Centurion, J. F. (2004). Effect of soil compaction in root development and in soybean yield. Pesq. Agropec. Bras., 39(6), 581-588. https://doi.org/10.1590/S0100-204X2004000600010

Carvalho, J. J., da Luz, J. M. R, Henrique, J., Silva, J. G. D., Silva, J. E. C., \& Santos, E. A. (2018). Biofertigation of forage with effluents of green line of a cattle slaughterhouse: Microbial diversity and leaf dry mass productivity. Journal of Agricultural Science, 10(5). https://doi.org/10.5539/jas.v10n5p353

CONAB (Companhia Nacional de Abastecimento). (2018). Safra 2016/2017. Retrieved from https://www.embrapa.br/soja/cultivos/soja1/dados-economicos

Cornejo, P., Azcon-Aguilar, C., Barea, J. M., \& Ferrol, N. (2004). Temporal Temperature Gradient Gel Electrophoresis (TTGE) as a tool for the characterization of arbuscular mycorrhizal fungi. FEMS Microbiology Letters, 241, 265-270. https://doi.org/10.1016/j.femsle.2004.10.030

Da Silva, M. R. S. S. (2012). Diversidade de comunidades bacterianas de solo de Cerrado em resposta a diferentes alterações dos ecossistemas (p. 140, Tese, Universidade de Brasília).

Direito, I. C. N., \& Teixeira, K. R. S. (2002). Simulação e comportamento de migração de produtos da amplificação parcial do gene nifH quando submetidos ao DGGE. Revista Universidade Rural, 22, 123-129.

Exame Magazine. (2018). Retrieved from https:/exame.abril.com.br/economia/alta-do-pib-de-2018-sobe-para289-na-projecao-do-focus

Faleiro, F. G. (2011). Aplicações de marcadores moleculares como ferramenta auxiliar em programas de conservação, caracterização e uso de germoplasma e melhoramento genético vegetal. In F. G. Faleiro, \& de S. R. M. Andrade (Eds.), Biotecnologia: estado da arte e aplicações na agropecuária (p. 730). Embrapa Cerrados.

Genro Junior, S. A., Reinert, D. J., \& Reichert, J. M. (2004). Temporal variation of soil penetration resistance in a clayey oxisol under no-tillage and crop rotation. Rev. Bras. Ciênc. Solo, 28(3).

Gomes, N. C. M., Fagbola, O., Costa, R., Rumjanek, N. G., Buchner, A., Mendona-Hagler, L., \& Smalla, K. (2003). Dynamics of Fungal Communities in Bulk and Maize Rhizosphere Soil in the Tropics. Applied and Environmental Microbiology, 69, 3758-3766. https://doi.org/10.1128/AEM.69.7.3758-3766.2003

Helgason, T., Fitter, A. H., \&Young, J. P. W. (1998). Ploughing up the wood-wide web? Nature, 394(6692), 431. https://doi.org/10.1038/28764

Kowalchuk, G. A., De Souza, F. A., \& Van Veen, J. A. (2002). Community Analysis of Arbuscular Mycorrhizal Fungi Associated with Ammophila arenaria in Dutch Coastal Sand Dunes. Mol. Ecol, 11, 571-581. https://doi.org/10.1046/j.0962-1083.2001.01457.x

Madigan, M. T., Martinko, J. M., Dunlap, P. V., \& Clark, D. P. (2010). Microbiologia de Brock (12th ed., p. 1091). Porto Alegre: Artmed.

Monteiro, G. G., Utida, M. K., Oliveira, C. A., Novotny, E. H., Alvarenga, R. C., Oliveira, A. C., \& Marriel, I. E. (2004). Composição de Comunidades Microbianas de Seis Agroecossistemas em um Solo de Cerrado. Anais do XXV Congresso Nacional de Milho e Sorgo.

Moreira, F. M. S., \& Siqueira, J. O. (2006). Microbiologia e bioquímica do solo. Lavras: UFLA.

Pimentel-Gomes, F. (2000). Curso de estatística experimental (14th ed.). Piracicaba: Esalq-USP. 
Raij, B., Andrade, J. C., Cantarella, H., \& Quaggio, J. A. (2000). Análise química da fertilidade dos solos tropicais (p. 285). Campinas: IAC.

Rodrigues, O. D. (2007). Influência da comunidade microbiana do solo no estabelecimento de sauveiros iniciais de Atta sexdens rubropilosa Forel, 1908 (Hymenoptera: Formicidae) (p. 64, Dissertação, Universidade de São Paulo, Escola Superior de Agricultura "Luiz de Queiroz").

SEAGRO (Secretária de Agricultura e Pecuária do Estado do Tocantins). (2017). Retrieved from https://seagro.to.gov.br

Silva, J. G. D., da Luz, J. M. R., Henrique, Jacqueline, de Carvalho, J. J., \& da Silva, J. E. C. (2018). Domestic Wastewater for Forage Cultivation in Cerrado Soil. Journal of Agricultural Science, 10(10), 248. https://doi.org/10.5539/jas.v10n10p248

Silva, M. B. da, Kliemann, H. J., Silveira, P. M., \& Lanna, A. C. (2007). Soil biological attributes influenced by cover crops and management systems. Pesquisa Agropecuária Brasileira, 42, 1755-1761. https://doi.org/ 10.1590/S0100-204X2007001200013

Simon, L., Lalonde, M., \& Bruns, T. D. (1992). Specific amplification of $18 S$ fungal ribossomal genes from vesicular-arbuscular endomycorrhizal fungi colonizing roots. Applied and Environmental Microbiology, 58, 291-295.

Tormena, C. A., Silva, A. P., \& Libardi, P. L. (1998). Characterization of the least limiting water range of an oxisol under no-tillage. Revista Brasileira de Ciência do Solo, 22, 573-581. https://doi.org/10.1590/S010006831998000400002

Tortora, G. J., Funke, B. R., \& Case, C. L. (2014). Microbiologia (10th ed., p. 934). Porto Alegre: Editora Artmed.

Ueda, T., Suga, Y., Yahiro, N., \& Matsuguchi, T. (1995). Remarkable $\mathrm{N}_{2}$-fixing bacterial diversity detected in rice roots by molecular evolutionary analysis of nifH gene sequences. Journal Bacteriology, 177, 1414-1417. https://doi.org/10.1128/jb.177.5.1414-1417.1995

UNFPA/ONU. (2017). Situation of the World Population in 2017. Retrieved from http://unfpa.org.br/swop2017/ swop2017.pdf

Vainio, E. J., \& Hantula, J. (2000). Direct analysis of wood-inhabiting fungi using denaturing gradient gel electrophoresis of amplified ribosomal DNA. Mycol. Res., 104(8), 927-936. https://doi.org/10.1017/S09537 56200002471

Vilela, G. F., Pereira, M. J. Z., Klepker, D., Moreira, J. U. V., Vieira, P. F. M., Rabelo, C. F. S.,... Silva Neto, S. P. (2016). Cultivares de soja: Macrorregiões 4 e 5 norte e nordeste do Brasil. Embrapa Soja, Londrina/PR.

\section{Copyrights}

Copyright for this article is retained by the author(s), with first publication rights granted to the journal.

This is an open-access article distributed under the terms and conditions of the Creative Commons Attribution license (http://creativecommons.org/licenses/by/4.0/). 